\title{
Antibiotic susceptibility of bacterial agents in children with SAM: A single-centre cross-sectional study
}

\author{
Singh JK ${ }^{1}$, Bajaj $\mathbf{N}^{2}$, Pattnaik $D^{3}$, Singh $\mathbf{J}^{4}$ \\ ${ }^{1}$ Dr Jeetendra Kumar Singh, Senior Resident, Department of Pediatrics, ${ }^{2}$ Dr Naresh Bajaj, Associate Professor, \\ Department of Pediatrics, ${ }^{3}$ Dr Dipankar Pattnaik, Assistant Professor, Department of Microbiology, ${ }^{4}$ Dr Jyoti Singh, \\ Professor and Head, Department of Pediatrics; all authors are affiliated with Shyam Shah Medical College, Rewa, MP, \\ India.
}

Address of Correspondence: Dr. Naresh Bajaj, Associate Professor, Department of Pediatrics, Shyam Shah Medical College, Rewa, MP, India, Email: naresh30405@gmail.com

\begin{abstract}
Purpose: To evaluate bacterial and fungal infections, and antibiotic sensitivity in children with severe acute malnutrition. Methods: Design: Cross-sectional study. Setting: Severe Malnutrition Treatment Unit of Pediatric ward of a tertiary level hospital attached to a medical college located in Rewa, Madhya Pradesh, India. Participants: 100 Children with severe acute malnutrition aged 6-59 months. Blood, urine, CSF (cerebrospinal fluid) and pleural fluid samples were cultured and antibiotic sensitivity pattern determined. Results: Blood and urine culture were positive in $28(28 \%)$ and 16 (16\%), respectively, CSF and pleural fluid culture were positive in $12.5 \%$ ( 1 out of 8 ) and $100 \%$ (1 out of 1 ) cases, respectively. Gram-positive bacteria constitute 25 (56.82\%) of the total bacterial isolates, where Staphylococcus aureus was most common while Escherichia coli was leading gram-negative bacteria. Blood culture showed $78.57 \%$ grampositive bacteria predominantly coagulase-negative staphylococcus (28.57\%), S. aureus (25\%) and Enterococcus (25\%). Gram-negative blood bacterial isolates constitute equal proportions of E. coli and Klebsiella $10.71 \%$ each. Urine bacterial isolates constitute predominantly E. Coli (64.29\%) followed by Klebsiella (21.43\%). Bacterial isolates showed high level of susceptibility to amikacin (76.19\%) followed by tetracycline $(57.14 \%)$ and gentamcin $(44.19 \%)$. Low level of susceptibility was observed to ampicillin (11.36\%), ciprofloxacin (16.67\%) and co-trimoxazole (20.59\%). Conclusions: Bacteraemia affected $28 \%$ children with severe acute malnutrition predominantly gram-positive isolates. Urine culture was dominated by gram-negative bacteria mostly E. Coli. Most bacterial isolates were resistant to commonly used antibiotics. Current guidelines for antibiotic of choice need to be reviewed.
\end{abstract}

Keywords: Bacteraemia; Gram-positive; Gram-negative; Antibiotic.

\section{Introduction}

Malnutrition in children is a major global public health concern in developing countries around the world, with wide implications. Although preventable child mortality continues to decrease, undernutrition is responsible for $45 \%$ of deaths of children younger than 5 years, amounting to more than 3 million deaths each year [1]. The child prevalence of malnutrition in India is twice that of Sub-Saharan Africa and more than one third of the world's children who are wasted live in India.

Malnourished children have a higher risk of invasive bacterial infections, causing bacterial pneumonia [2],

Manuscript received: $4^{\text {th }}$ August 2016

Reviewed: $16^{\text {th }}$ August 2016

Author Corrected; $28^{\text {th }}$ August 2016

Accepted for Publication: $15^{\text {th }}$ September 2016 bacterial diarrhoea $[3,4]$, and bacteraemia $[5,6]$, with a predominance of gram negative bacteria. Since most infections and deaths in malnourished children occur in low-income settings, the organisms causing disease are rarely identified.

Therefore, little is known about whether these differ from pathogens infecting well-nourished children, and whether malnourished children are susceptible to opportunistic infections. Most data on infections in malnourished children come from Africa. There has been very little information on infections in children with Severe Acute Malnutrition (SAM) from India, despite the heavy burden of malnutrition in this region. 


\section{Material and Methods}

This descriptive cross-sectional study was conducted over a 7-month period from March 2014 to September 2014 in the Severe Malnutrition Treatment Unit of Pediatric Ward of Gandhi Memorial Hospital, which is a tertiary level hospital attached to a Medical College in Rewa, Madhya Pradesh. This study was initiated after getting approval from the institutional ethics committee. Study population included children with SAM with or without complications, aged 6-59 months admitted during study period. Children who had taken any antibiotics within one week prior to presentation, or those who died before taking necessary investigations were excluded from the study. Informed consent was obtained from all individual participants included in the study. SAM was diagnosed if any 1 of the 3 were present: weight for height / length <-3SD, mid upper arm circumference $<11.5 \mathrm{~cm}$ or presence of nutritional edema [7]. A standardized clinical form was used to collect sociodemographic information, clinical symptoms and their duration, immunization history, anthropometric measurements, physical signs, results of laboratory investigations, and the patient's final outcome. Before antibiotic administration blood and urine samples were collected from all patients, and other relevant body fluid samples (cerebrospinal fluid and pleural fluid) when indicated were taken for isolation of bacterial and fungal pathogens.

Blood was obtained for culture by venepuncture after the intact skin was cleansed with $70 \%$ ethyl alcohol for a minimum of 30 seconds followed by application of Iodine solution (10\% Povidone Iodine) for another 30 seconds in a concentric circle away from the puncture site covering a circular area of 1 to 2 inches in diameter.
Two $\mathrm{ml}$ of blood from 2 different sites were collected and inoculated into 2 blood culture bottles containing $20 \mathrm{ml}$ of Brain-Heart Infusion (BHI) broth (HiMedia lab. Mumbai, India). Subcultures were performed onto blood agar, chocolate agar, and Mac Conkey agar plates after 24 hours of incubation at $37^{\circ} \mathrm{C}$. Blood cultures were considered positive if a definite pathogen was isolated. The bacterial isolates were identified based on their Gram reaction, colony morphology and biochemical tests. Mixed growths were considered as contaminants or negative. Finally, culture bottles that did not show growth were further incubated for 7 days. If still no turbidity was observed a small portion of the culture broth was inoculated on the media listed above before being reported as negative.

Urine was collected by urethral catheterization or collection of a freshly voided "clean-catch" specimen. Where catheterization was performed, the external genitalia were cleansed. All urine samples were examined microscopically and plated onto blood agar, chocolate agar, and MacConkey agar using a standardized loop. Plates were incubated aerobically at $37^{\circ} \mathrm{C}$ overnight and examined for growth the following morning. CSF and pleural fluid were collected by lumbar puncture and pleural tap under aseptic conditions. The diagnosis of bacteriuria was based on the finding of any bacterial growth $>10^{5}$ colonies $/ \mathrm{mL}$ of urine obtained from a freshly voided specimen. For fungal culture Sabouraud's Dextrose Agar (HiMedia lab. Mumbai, India) was used. Antibiotic sensitivity patterns of bacterial isolates were determined by KirbyBauer disk diffusion method using inter-pretative criteria described previously.

\section{Results}

A total of 192 SAM children were admitted, of which 100 were enrolled in the study. Majority of the patients 94 (94\%) were 35 months old or younger. The mean age at enrolment was 13.72 months, 57 (57\%) were males (Table 1). Fever was the commonest presenting complaint seen in $88 \%$ cases. Children presented with loose stool, rapid breathing and cough/cold in $41 \%, 40 \%$ and $37 \%$ cases respectively. Vomiting in $21 \%$ and abnormal body movement was presenting complaint in $12 \%$ cases. Ten $(10 \%)$ children presented with edema.

There were 28 positive blood cultures all of which grew bacterial pathogens. Urine samples were positive for bacterial pathogen in $14 \%$ cases, and fungal isolate in $2 \%$ cases. Both fungus were Candida. CSF and pleural fluid culture were positive for bacterial pathogen in $12.5 \%$ ( 1 out of 8 ) and 100\% (1 out of 1) cases, respectively with no fungal isolate.

Gram-positive bacteria constitute $25(56.82 \%)$ of the total bacterial isolates, where Staphylococcus aureus was most common while Escherichia coli was leading gram-negative bacteria. Blood culture showed $78.57 \%$ gram-positive bacteria predominantly coagulase-negative staphylococcus $(28.57 \%)$, S. aureus $(25 \%)$ and Enterococcus $(25 \%)$. Gramnegative blood bacterial isolates constitute equal proportions of E. coli and Klebsiella 10.71\% each. Urine bacterial isolates constitute predominantly E. coli $(64.29 \%)$ followed by Klebsiella $(21.43 \%)$. CSF culture showed S. aureus and 
pleural fluid showed E. coli growth. There was no significant difference in proportions of bacterial isolates by age, sex and presence / absence of edema.

Table-1: Characteristics of 100 children aged 6-59 months with Severe Acute Malnutrition.

\begin{tabular}{|c|c|}
\hline Characteristic & Participants \\
\hline Median age & 13.72 \\
$<12$ months & $51(51.00 \%)$ \\
$\geq 12$ months & $49(49.00 \%)$ \\
\hline Sex & \\
Male & $57(57.00 \%)$ \\
Female & $43(43.00 \%)$ \\
\hline Death & $6(6.00 \%)$ \\
\hline Presenting complaints & $88(88.00 \%)$ \\
Cough & $37(37.00 \%)$ \\
Loose stool & $41(41.00 \%)$ \\
Vomiting & $30(30.00 \%)$ \\
Rapid breathing & $40(40.00 \%)$ \\
Edema & $10(10.00 \%)$ \\
\hline Culture positive & \\
Blood & $28(28.00 \%)$ \\
Urine & $16(16.00 \%)$ \\
CSF & $1 / 8(12.50 \%)$ \\
Pleural fluid & $1 / 1(100 \%)$ \\
\hline
\end{tabular}

In vitro sensitivity of the blood bacterial isolates (Table 2) showed highest sensitivity to amikacin (85.19\%) and least to ampicillin (10.71\%) and cefotaxime (16.67\%). Similar pattern was also seen in urinary bacterial isolates (Table 3 ). Overall bacterial isolates (Table 4) by showed high level of susceptibility to amikacin (76.19\%) followed by tetracycline $(57.14 \%)$ and gentamcin $(44.19 \%)$. Low level of susceptibility was observed to cefotaxime (10.00\%), ampicillin (11.36\%), ciprofloxacin (16.67\%) and co-trimoxazole (20.59\%).

Table-2: Antibiotic susceptibility of blood bacterial isolates.

\begin{tabular}{|c|c|c|c|c|c|c|}
\hline \multirow[b]{2}{*}{ Antibiotics } & \multicolumn{5}{|c|}{ Number of susceptible organism/Number tested (\%) } & \multirow[b]{2}{*}{ Total } \\
\hline & $\begin{array}{c}\text { S. aureus } \\
(\mathrm{N}=7)\end{array}$ & $\begin{array}{l}\text { CONS } \\
(N=8)\end{array}$ & $\begin{array}{c}\text { Enterococcus } \\
(\mathrm{N}=7)\end{array}$ & $\begin{array}{l}\text { E. coli } \\
(\mathrm{N}=3)\end{array}$ & $\begin{array}{l}\text { Klebsiella } \\
\qquad(\mathrm{N}=3)\end{array}$ & \\
\hline Amikacin & $7 / 7(100 \%)$ & $7 / 8(87.50 \%)$ & $5 / 7(71.43 \%)$ & $2 / 3(66.67 \%)$ & $2 / 2(100 \%)$ & $\begin{array}{c}23 / 27 \\
(85.19 \%)\end{array}$ \\
\hline Ampicillin & $0 / 7(0.00 \%)$ & $2 / 8(25.00 \%)$ & $1 / 7(14.29 \%)$ & $0 / 3(0.00 \%)$ & $0 / 3(0.00 \%)$ & $3 / 28(10.71 \%)$ \\
\hline Cefoperazone & NT & NT & NT & $1 / 3(33.33 \%)$ & NT & $1 / 3(33.33 \%)$ \\
\hline Cefotaxime & NT & NT & NT & $1 / 3(33.33 \%)$ & $0 / 3(0.00 \%)$ & $1 / 6(16.67 \%)$ \\
\hline Cephalexin & $1 / 7(14.29 \%)$ & $0 / 8(0.00 \%)$ & $1 / 4(25.00 \%)$ & $0 / 3(0.00 \%)$ & $0 / 3(0.00 \%)$ & $2 / 25(8.00 \%)$ \\
\hline Ciprofloxacin & $0 / 7(0.00 \%)$ & $1 / 8(12.50 \%)$ & $1 / 6(16.67 \%)$ & $2 / 2(100 \%)$ & $0 / 3(0.00 \%)$ & $4 / 26(15.38 \%)$ \\
\hline Cotrimoxazole & $0 / 7(0.00 \%)$ & $0 / 7(0.00 \%)$ & NT & $2 / 3(66.67 \%)$ & $0 / 3(0.00 \%)$ & $2 / 20(10.00 \%)$ \\
\hline Erythromycin & $1 / 5(20.00 \%)$ & $3 / 8(37.50 \%)$ & $2 / 6(33.33 \%)$ & $0 / 1(0.00 \%)$ & NT & $6 / 20(30.00 \%)$ \\
\hline Gentamicin & $5 / 7(71.43 \%)$ & $4 / 8(50.00 \%)$ & $3 / 7(42.86 \%)$ & $2 / 3(66.67 \%)$ & $2 / 3(66.67 \%)$ & $16 / 28(57.14 \%)$ \\
\hline Norfloxacin & NT & NT & NT & NT & NT & NT \\
\hline Tetracycline & $3 / 7(42.86 \%)$ & $6 / 6(100 \%)$ & $4 / 6(66.67 \%)$ & $2 / 3(66.67 \%)$ & $2 / 3(66.67 \%)$ & $17 / 25(68.00 \%)$ \\
\hline
\end{tabular}

CONS $=$ Coagulase-negative staphylococcus, $\mathrm{N}=$ Number of isolates, $\mathrm{NT}=$ Not teste 
Table-3: Antibiotic susceptibility of urinary bacterial isolates.

\begin{tabular}{|c|c|}
\hline Antibiotics & Susceptibility of urinary bacterial isolates \\
\hline Amikacin & $7 / 13(53.85 \%)$ \\
\hline Ampicillin & $2 / 14(14.29 \%)$ \\
\hline Cefoperazone & $1 / 10(10.00 \%)$ \\
\hline Cefotaxime & $1 / 13(7.69 \%)$ \\
\hline Cephalexin & $1 / 12(8.33 \%)$ \\
\hline Ciprofloxacin & $3 / 14(21.43 \%)$ \\
\hline Cotrimoxazole & $4 / 13(30.77 \%)$ \\
\hline Erythromycin & $1 / 2(50.00 \%)$ \\
\hline Gentamicin & $2 / 13(15.38 \%)$ \\
\hline Norfloxacin & $2 / 3(66.67 \%)$ \\
\hline Tetracycline & $5 / 14(35.71 \%)$ \\
\hline
\end{tabular}

Table-4: Antibiotic susceptibility of all bacterial isolates in relation to the number tested.

\begin{tabular}{|c|c|}
\hline Antibiotics & Total \\
\hline Amikacin & $\begin{array}{c}32 / 42 \\
(76.19 \%)\end{array}$ \\
\hline Ampicillin & $\begin{array}{c}5 / 44 \\
(11.36 \%)\end{array}$ \\
\hline Cefoperazone & $\begin{array}{c}2 / 14 \\
(14.29 \%)\end{array}$ \\
\hline Cefotaxime & $\begin{array}{c}2 / 20 \\
(10 \%)\end{array}$ \\
\hline Cephalexin & $\begin{array}{c}4 / 39 \\
(10.26 \%)\end{array}$ \\
\hline Ciprofloxacin & $\begin{array}{c}7 / 42 \\
(16.67 \%)\end{array}$ \\
\hline Cotrimoxazole & $\begin{array}{c}7 / 34 \\
(20.59 \%)\end{array}$ \\
\hline Erythromycin & $\begin{array}{c}8 / 23 \\
(34.78 \%)\end{array}$ \\
\hline Gentamicin & $\begin{array}{c}19 / 43 \\
(44.19 \%)\end{array}$ \\
\hline Norfloxacin & $\begin{array}{c}2 / 3 \\
(66.67 \%)\end{array}$ \\
\hline Tetracycline & $\begin{array}{c}24 / 42 \\
(57.14 \%)\end{array}$ \\
\hline
\end{tabular}

\section{Discussion}

We have studied bacterial and fungal isolates, and antibiotic sensitivity of bacterial isolates among 100 children aged 6-59 months of age with SAM admitted to Severe Malnutrition Treatment Unit of Pediatric Ward of a tertiary level hospital attached to a medical college located in Rewa. The prevalence of bacteraemia was $28 \%$ in children with severe malnutrition in this study is similar to that reported across Sub-Saharan Africa in which the prevalence of bacteraemia ranged from $8.6 \%$ to $70 \%$ in West Africa $[8,9], 9.2 \%$ to $36 \%$ in East Africa [10-13], and $7.7 \%$ to $13 \%$ in South Africa [14, 15]. Causative agents of bacteraemia, 
however, vary geographically with most studies reporting a predominance of Gram-negative enteric bacteria (GNEB) [10-12, 14] and a few in which Grampositive aerobes predominated, mostly Staphylococcus species $[8-9,15]$. In our study, Gram-positive aerobes accounted for $78.57 \%$ of the bacteraemic episodes, with coagulase-negative staphylococcus $(28.57 \%)$, being the most common isolate immediately followed by $S$. aureus (25\%) and Enterococcus (25\%). Studies from several different regions have reported CONS rates in blood cultures ranging from 26.7 to $40 \%$ [12, 15-16]. However, CONS are prominent components of the microbial skin flora, and any interruption in the normal skin defence barrier as may occur in severe malnutrition facilitates entry of these organisms into the bloodstream with resultant bacteraemia [15]. Moreover, CONS are well recognized as a significant cause of sepsis among critically ill and immunosuppressed children. There was no significant difference in bactaeremia in children having diarrhea and pneumonia.

The prevalence of bacteriuria of $14 \%$ reported in our study is consistent with most other studies in which urine isolation rates varied between $5 \%$ and $35 \%[9,12$, 17-18]. The finding of Escherichia coli (64.29\%) and Klebsiella $(21.43 \%)$ species as the predominant urinary pathogens is also consistent with reports from previous studies where these pathogens accounted for up to $62.5 \%$ and $12.5 \%$ of urine isolates respectively [18-20].

The current study shows that there has been a change in the blood bacterial isolates susceptibility to antibiotics by showing low susceptibility to commonly used antibiotics. Acquired bacterial resistance to first-line broad-spectrum antibiotics is increasingly common and is a significant cause of mortality [20]. WHO recommends the use of a combination of intravenous ampicillin and once daily intravenous or intramuscular gentamicin. In our study bacterial isolates showed high level of susceptibility to amikacin $(76.19 \%)$ followed by tetracycline $(57.14 \%)$. Susceptibility to gentamicin was below $50 \%$. Low level of susceptibility was observed to ampicillin (11.36\%), ciprofloxacin (16.67\%) and co-trimoxazole (20.59\%). Two studies have shown higher mortality in the bacteraemic group compared to non bacteraemic group. However it was not documented if the difference was of statistical significance $[10,14]$. The lack of statistical significance in the finding of our study could be a reflection of comorbidities other than bacteraemia to be the cause of deaths, or could be due to the predominance of less fatal Gram positive microbes.
Study limitations: Our data are limited by being from only one hospital; its finding might reflect selection bias and the results cannot be generalized countrywide. Sample size is small and no controls were taken for comparison. Isolation of anaerobic microbes was not done due to financial constraints.

\section{Conclusions}

Our study confirms the high level of infections among children with SAM and that diagnosis based only on clinical signs and isolated tests, is poorly indicative of the type of infection in this population. Our results reinforce current calls to implement robust strategies for limiting the emergence of antibiotic-resistant bacterial strains. Furthermore, expanding both descriptive and interventional studies on the treatment of malnourished populations is essential for addressing the needs of this vulnerable population.

\section{Funding: Nil, Conflict of interest: Nil Permission from IRB: Yes}

\section{References}

1. Black RE, Victora CG, Walker SP, Bhutta ZA, Christian P, de Onis M, Ezzati M, Grantham-McGregor S, Katz J, Martorell R, Uauy R; Maternal and Child Nutrition Study Group. Maternal and child undernutrition and overweight in low-income and middleincome countries. Lancet. 2013 Aug 3; 382 (9890):42751. doi: 10.1016/S0140-6736(13) 60937-X. Epub 2013 Jun 6 .

2. Ikeogu MO Wolf B, Mathe S. Pulmonary manifestations in HIV seropositivity and malnutrition in Zimbabwe. Arch Dis Child. 1997 Feb;76(2):124-8.

3. Mondal D, Haque R, Sack RB, Kirkpatrick BD, Petri WA Jr. Attribution of malnutrition to cause-specific diarrheal illness: evidence from a prospective study of preschool children in Mirpur, Dhaka, Bangladesh. Am J Trop Med Hyg. 2009 May;80(5):824-6.

4. Khatun F, Faruque AS, Koeck JL, Olliaro P, Millet P, Paris N, Malek MA, Salam MA, Luby S. Changing species distribution and antimicrobial susceptibility pattern of Shigella over a 29-year period (1980-2008). Epidemiol Infect 2011 Mar;139(3): 446-52. doi: 10. 1017/S0950268810001093. Epub 2010 May 18.

5. Berkley JA, Lowe BS, Mwangi I, Williams T, Bauni E, Mwarumba S, Ngetsa C, Slack MP, Njenga S, Hart CA, Maitland K, English M, Marsh K, Scott JA. 
Bacteremia among children admitted to a rural hospital in Kenya. N Engl J Med. 2005 Jan 6;352(1):39-47.

6. Aiken AM, Mturi N, Njuguna P, Mohammed S, Berkley JA, Mwangi I, Mwarumba S, Kitsao BS, Lowe BS, Morpeth SC, Hall AJ, Khandawalla I, Scott JA; Kilifi Bacteraemia Surveillance Group. Risk and causes of paediatric hospital-acquired bacteraemia in Kilifi District Hospital, Kenya: a prospective cohort study. Lancet. 2011 Dec 10;378(9808):2021-7. doi: 10.1016/ S0140-6736 (11)61622-X. Epub 2011 Nov 29.

7. WHO Multicentre Growth Reference Study Group. WHO child growth standards: methods and development. Growth velocity based on weight, length and head circumference. Geneva: World Health Organization; 2009 (www. who. Int / childgrowth/ standards/velocity/technical_report/en/index.html, accessed 30 August 2013)

8. Hill PC, Onyeama CO, Ikumapayi UN, Secka O, Ameyaw S, Simmonds N, Donkor SA, Howie SR, Tapgun M, Corrah T, Adegbola RA. Bacteraemia in patients admitted to an urban hospital in West Africa. BMC Infectious Dis. 2007 Jan 26;7:2.

9. Ekanem EE, Umotong AB, Raykundalia C, Catty D. Serum C-reactive protein and $\mathrm{C} 3$ complement protein levels in severely malnourished Nigerian children with and without bacterial infections. Acta Paediatrica. 1997 Dec;86(12):1317-20.

10. Babirekere-Iriso E, Musoke $\mathrm{P}$, Kekitiinwa A. Bacteraemia in severely malnourished children in an HIV-endemic setting. Ann Trop Paediatr. 2006 Dec;26 (4):319-28.

11. Bachou H, Tylleskar T, Kaddu-Mulindwa DH, and Tumwine JK. "Bacteraemia among severely malnourished children infected and uninfected with the human immunodeficiency virus-1 in Kampala, Uganda. BMC Infectious Dis. 2006 Nov 7;6:160.
12. Noorani N, Macharia WM, Oyatsi D, Revathi G. Bacterial isolates in severely malnourished children at Kenyatta National Hospital, Nairobi. East Afr Med J. 2005 Jul;82(7):343-8.

13. Friedland IR. Bacteraemia in severely malnourished children. Ann Trop Paediatr. 1992;12(4):433-40.

14. Reed RP, Wegerhoff FO, Rothberg AD. Bacteraemia in malnourished rural African children. Ann Trop Paediatr. 1996 Mar;16(1):61-8.

15. Christie CD, Heikens GT, Golden MH. Coagulasenegative staphylococcal bacteremia in severely malnourished Jamaican children. Pediatr Infect Dis J. 1992 Dec;11(12):1030-6.

16. von Eiff C, Peters G, Heilmann C. Pathogenesis of infections due to coagulase-negative staphylococci. Lancet Infect Dis. 2002 Nov;2(11):677-85.

17. Rabasa AI, Shattima D. Urinary tract infection in severely malnourished children at the University of Maiduguri Teaching Hospital. J Trop Pediatr. 2002 Dec;48(6):359-61.

18. Reed RP and Wegerhoff FO. Urinary tract infection in malnourished rural African children. Ann Trop Paediatr. 1996 Mar;16(1):61-8.

19. Banapurmath CR and Jayamony S. Prevalence of urinary tract infection in severely malnourished preschool children. Indian Pediatr. 1994 Jun;31(6): 679-82.

20. Blomberg B, Manji KP, Urassa WK, Tamim BS, Mwakagile DS, Jureen R, Msangi V, Tellevik MG, Holberg-Petersen M, Harthug S, Maselle SY, Langeland N. Antimicrobial resistance predicts death in Tanzanian children with bloodstream infections: a prospective cohort study. BMC Infect Dis. 2007 May $22 ; 7: 43$.

\section{How to cite this article?}

Singh JK, Bajaj N, Pattnaik D, Singh J. Antibiotic susceptibility of bacterial agents in children with SAM: A singlecentre cross-sectional study. Int J Pediatr Res.2016;3(9):672-677.doi:10.17511/ijpr.2016.i09.08. 